\title{
Application of microbial fuel cell technology for vinasse treatment and bioelectricity generation
}

\author{
Cristiane Angélica Ottoni $(\mathbb{D} \cdot$ Marta F. Simões $\cdot$ Jonas G. Santos $\cdot$ \\ Luciana Peixoto - Cleiton R. Martins • Bruno P. Silva - Almir O. Neto • \\ António G. Brito • Alfredo E. Maiorano
}

Received: 26 July 2018/ Accepted: 12 November 2018/Published online: 15 November 2018

(C) Springer Nature B.V. 2018

\begin{abstract}
Objective Our study evaluated the performance of different two-chambered microbial fuel cell (MFC) prototypes, operated with variable distance between electrodes and Nafion membrane and specific inoculum concentration, applied for vinasse treatment.

Results The performance of the developed MFC resulted in a maximum current density of $1200 \mathrm{~mA} \mathrm{~m}^{-2}$ and power density of $800 \mathrm{~mW} \mathrm{~m}^{-2}$ in a period of 61 days. MFC performed a chemical oxygen demand removal at a rate ranging from 51 to $60 \%$.
\end{abstract}

C. A. Ottoni $(\bowtie)$ C C. R. Martins · B. P. Silva

São Paulo State University (UNESP), Bioscience Institute, São Vicente, SP 11380-972, Brazil e-mail: cristiane.ottoni@unesp.br;

cris.a.ottoni@gmail.com

\section{F. Simões}

Biology Department, Edge Hill University, St Helens

Road, Lancashire, Ormskirk L39 4QP, UK

C. A. Ottoni - J. G. Santos - A. E. Maiorano Laboratório de Biotecnologia Industrial, Instituto de Pesquisas Tecnológicas do Estado de São Paulo,

São Paulo, SP 05508-901, Brazil

\section{Peixoto}

Centre of Biological Engineering, University of Minho, Campus of Gualtar, 4710-057 Braga, Portugal
Conclusions Taking our preliminary results into consideration, we concluded that the MFC technology presents itself as highly promising for the treatment of vinasse.

Keywords Microbial fuel cell · Vinasse $\cdot$ Chemical oxygen demand $\cdot$ Bioelectricity

\section{Introduction}

The alarming increase in the growing demand for energy sources, coupled with uncertainty regarding
A. O. Neto
Centro de Célula a Combustível e Hidrogênio, Instituto de Pesquisas Energéticas e Nucleares, São Paulo, SP 05508-000, Brazil
A. G. Brito
Department of Biosystems Sciences and Engineering, Institute of Agronomy, University of Lisbon, Tapada da Ajuda, 1349-017 Lisbon, Portugal 
availability and price of oil, leads to the adoption of practices for the development and exploitation of new energy resources for a sustainable growth in society (Yang et al. 2012; Hassan et al. 2014; Sá et al. 2014). Among the biofuels obtained from renewable raw materials, sugarcane ethanol is an example of one that can make a substantial contribution in terms of amount of residue produced-vinasse (Harde et al. 2014; Moraes et al. 2014). In the crop year 2013/2014, the total ethanol production reached 13.9 thousand $\mathrm{m}^{3}$ (Martínez et al. 2013; Cassman et al. 2018). However, although this fuel is a renewable resource, approximately 9-14 L of vinasse is originated from each liter of ethanol produced (Engin et al. 2018).

Vinasse has a complex composition, with low biochemical oxygen demand $\left(\mathrm{BOD}_{5}\right)$, high chemical oxygen demand (COD), low $\mathrm{pH}$ and, rich in organic and mineral substances, predominantly potassium. This can cause changes in the physical and chemical properties of soils that receive frequent discharges of this residue, resulting in harmful effects to agriculture and biota in general (Potentini and Rodríguez-Malavera 2006; Santos et al. 2014; Sydney et al. 2014). Vinasse can also be a significant source of greenhouse gas emissions into the atmosphere, due to the aerobic and anaerobic decomposition of organic matter that occurs during its transport, temporary storage or even disposal (Oliveira et al. 2013).

Since vinasse is rich in carbon and some potassium and calcium salts, it can be an important substrate for microbial growth, with great potential for bioprocesses (Campos et al. 2014). Recently, vinasse has been described as a carbon source for the production of biosurfactants (Lima and Souza 2013; Oliveira and Garcia-Cruz 2013). Treatment of vinasse by anaerobic digestion is a promising approach, since the byproducts of this process, methane $\left(\mathrm{CH}_{4}\right)$ and other gases, are produced in sufficient amount to generate 3.6-10.6 MW of electricity when the BOD of vinasse assumes values between 17,000 and 50,000 $\mathrm{mg} \mathrm{L}^{-1}$. However, such process is not yet economically viable (Higa et al. 2014). Christofoletti et al. (2013) reported a number of applications of this residue (e.g.: fertigation, animal feed, biodigestion/biogas, combustion in boilers, protein production). But, most of these largescale applications lack further studies and are costly.

In addition to the applications described, the use of microbial fuel cells (MFCs) is a promising technology applicable for vinasse biotreatment, since several substrates such as: hydrolyzed maize straw, domestic wastewater, effluent paper processing, recycled paper and organic matter from the aquatic sediment, are complex substrates that have also been used in MFCs for electric power generation and waste treatment (Pant et al. 2010; Zhang et al. 2011; Hidalgo et al. 2014).

The MFCs typically comprise an anode compartment and a cathodic compartment separated by a proton conducting membrane. In the anode compartment, the microorganisms oxidise the organic matter, under anaerobic conditions, producing protons and electrons (Peixoto et al. 2013; Jadhav et al. 2014). The electrons pass through an external circuit, generating electric current. The protons cross the membrane towards the cathode. Finally, the electrons and protons combine with the oxygen present at the cathode to form water.

Many are the factors that influence the performance of MFCs: nature of the materials used in the electrodes and distance between them, substrates used, microbial inoculum, reactor configuration, ionic strength, internal and external resistances, presence or absence of a proton exchange membrane (PEM) and, the properties of the catalysts (Franks and Nevin 2010; Higgins et al. 2011; Huang et al. 2011; Hou et al. 2012; Ozkaya et al. 2012; Mehdinia et al. 2014). However, an important limitation in the generation of energy from MFCs are the electrodes. Recently, many studies have been focusing on the different possible materials used in the electrodes and their configuration. Over the last decade, a variety of electrodes have been extensively explored for MFCs (Wei et al. 2011). Bacterial adhesion, electron transfer and oxidation of substrates are factors that depend directly on the performance of the electrode (Alatraktchi et al. 2011).

The generation of electricity by MFC technology is generally described according to the microbial composition of the biofilm on the anode, which plays an important role in the decomposition process of the substrate. However, rapid microbial growth can easily block the pores of the materials used in the electrodes and thus prevent the diffusion of the substrate. Nevertheless, studies related to the importance of biofilm formation are still limited. Furthermore, MFCs have great potential for expanding current knowledge on the phylogenetic and functional diversity of complex microbial communities, especially when combined with molecular approaches, including 
DNA barcoding and metagenomics (Chakraborty et al. 2014).

Considering all of the above, MFC technology is now regarded as a renewable energy generation system to tackle the existing energy demand and pollution problems in an integrated and sustainable approach. Despite all progress in MFC research, this still faces many challenges. A comprehensive understanding of the various factors that compromise their full performance is imperative, since losses of electrons during the MFC operation are a major obstacle that limits the output power (Mohan et al. 2014).

Regarding the use of vinasse, there are no reports on the use of this technology. Thus, the main objective of this study was to present a sustainable MFC for the reduction of the vinasse organic matter and its conversion into bioenergy.

\section{Materials and methods}

MFC description and operation

The dual chamber MFC prototype (Fig. 1), made of polyvinyl chloride (PVC), consisted of two compartments with equal dimensions, physically separated by a PEM (Nafion Membrane 117, DuPont Co., USA), sealed with a silicone rubber. Once assembled, the prototype was sterilised by immersion in a $30 \%$ chlorine (bleach) solution for $30 \mathrm{~min}$, followed by several rinsing steps with sterile distilled water.

The volume of each chamber was $50 \mathrm{~mL}$ with $45 \mathrm{~mL}$ of liquid volume. The electrodes, carbon cloth $\left(3 \mathrm{~cm} \times 3 \mathrm{~cm}=9 \mathrm{~cm}^{2}\right)$, were connected to an external resistance using stainless steel. The circuit was closed with a fixed resistance of $1 \mathrm{k} \Omega$, determined after performance assessment. MFC prototypes were constructed, one with a $3 \mathrm{~cm}$ distance between the electrodes and the PEM; and another with no distance between the electrodes and the PEM.

The anode chamber was filled by vinasse supplied by the Brazilian Sugarcane Industry (São Martinho, Iracema), with an average COD concentration of $24.000 \mathrm{mg} \mathrm{O}_{2} \mathrm{~L}^{-1}$, conductivity of $15.69 \pm 20 \mathrm{~S} \mathrm{~cm}^{-1}$ and $\mathrm{pH} 4.5 \pm 0.2$. The microbial inoculum, with undefined composition, of vinasse anaerobic digestion inoculum from an upflow anaerobic sludge blanket reactor (UASBR), was added to the previously mentioned vinasse in the anode chamber, at a $10-30 \%$ concentration.

The cathode chamber was filled with synthetic medium (PBS: $80 \mathrm{~g} \mathrm{~L}^{-1} \mathrm{NaCl}, 2 \mathrm{~g} \mathrm{~L}^{-1} \mathrm{KCl}$, $11.5 \mathrm{~g} \mathrm{~L}^{-1} \mathrm{Na}_{2} \mathrm{HPO}_{4}, 2 \mathrm{~g} \mathrm{~L}^{-1} \mathrm{KH}_{2} \mathrm{PO}_{4}$ ).

The MFC was maintained at $30{ }^{\circ} \mathrm{C}$ for 61 days. All the experiments were done in triplicate and, a control experiment, also done in triplicate, was performed with a similar MFC apparatus. The control MFC was operated simultaneously with the same conditions described above, except the use of the inoculum in the cathode chamber where there was only vinasse.

From the two prototypes tested, the one with the best performance results was then used to analyse its performance at a new inoculum concentration of 20 and $30 \%$.

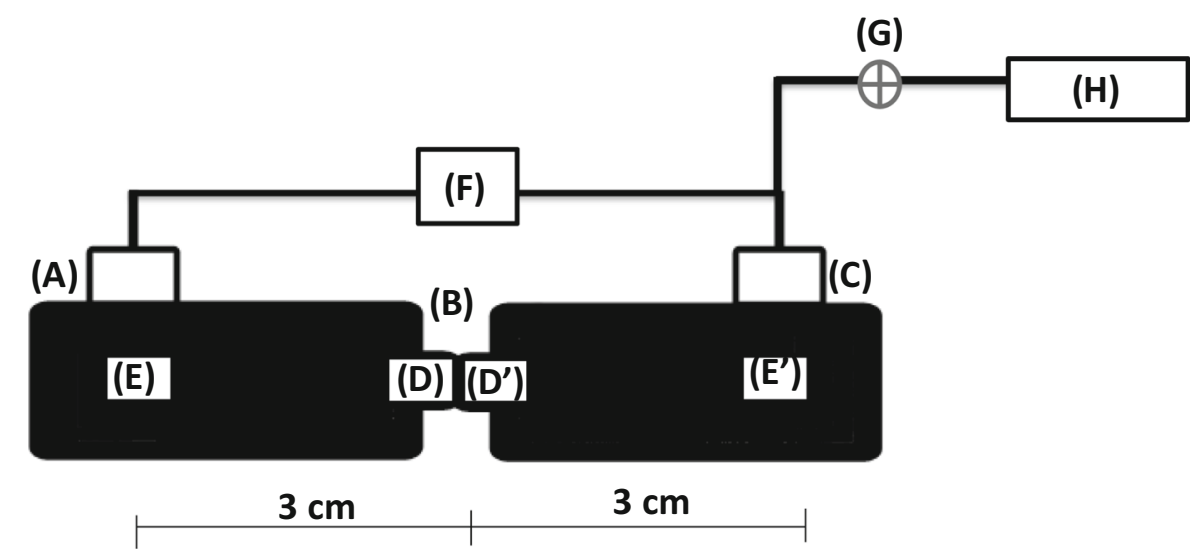

Fig. 1 Microbial fuel cell prototype: $(A)$ anode chamber, $(B)$ Nafion Membrane $117,(C)$ cathode chamber, $\left(D, D^{\prime}, E, E^{\prime}\right)$ electrodes in different positions, $(F)$ fixed resistance of $1 \mathrm{k} \Omega,(G)$ microbial filter, and $(H)$ aquarium pump 
Analytical methods

\section{Current density measurements}

MFC power output was monitored by measuring the voltage across a known resistance. Voltage measurements for long-term assays were collected daily using a manual multimeter. The current intensity (i) was determined according to the Ohm's law and the current density (I) was determined as I = i/A, where A is the projected surface area of the anode electrode.

The power density $(\mathrm{P})$ was determined as the product of current intensity and voltage divided by the surface area of the anode $(\mathrm{P}=\mathrm{i} \cdot \mathrm{V} / \mathrm{A})$.

\section{Chemical oxygen demand (COD) and sugar concentrations}

COD was measured in accordance with the standard methods (Sydney et al. 2014). The sugar concentrations (sucrose, fructose and glucose) in the samples were analyzed using high performance liquid chromatography with an Aminex HPX-87C column $(300 \times 7.8 \mathrm{~mm}$, Bio-Rad Laboratories) and, a system composed by a 510 pump, a refraction index differential detector and a data processor with register (Waters, USA). The samples were eluted with Milli-Q water at $0.6 \mathrm{~mL} \mathrm{~min}{ }^{-1}$ flow rate, and the temperature of the column was maintained at $72{ }^{\circ} \mathrm{C}$.

\section{Results and discussion}

Vinasse profile

The MFC prototype was operated in one batch cycle, with a $10 \%$ inoculum, to investigated the vinasse COD reduction and electricity generation (performed in three independent experiments). The main goal was to evaluate the influence of distances between electrodes and inoculum concentration in the MFC performance. Table 1 shows the variation of vinasse, $\mathrm{pH}$ and conductivity, during the experiment.

Depending of the electrode distance, the COD removal in the anodic compartment varied. After 61-64 days of MFC prototype operation, it ranged $51-54.5 \%$, when the MFC was operated with electrodes distant from the PEM, and it ranged 60-62\% when the MFC was operated with electrodes close to the PEM.

The consumption profile of the sugars that compose the synthetic vinasse during the process was also analysed (Table 2A, B). The time of consumption of the monosaccharides (glucose and fructose) occurred between the 7th and the 14th day, while the consumption of sucrose occurred between the 8 th and the $21 \mathrm{st}$ day.

These results confirm the presence of a microbial load in the anode chamber. The microbial composition of the inoculum was not determined for this research, but according to previous studies (Christofoletti et al. 2013), it is mainly bacterial, with low alpha diversity, the main genus being Lactobacillus, but high percentage of microbial denitrifiers, with many unknown species with a high potential of being novel taxa developed by the adaptation to the anaerobic and extreme conditions usually found in UASBR.

Bioelectricity generation

\section{Effect of electrodes on MFC performance}

During the MFCs operation, current and power density were recorded. Initially, the effect of the distance

Table 1 Profile of vinasse and MFC chambers before and after experiment

\begin{tabular}{lccc}
\hline Vinasse & In nature & Anode vinasse + inoculum & Cathode \\
\hline $\mathrm{pH}$ (initial) & 4.54 & 5.53 & 6.95 \\
$\mathrm{pH}($ final) electrodes close PEM & 4.46 & 4.65 & 5.43 \\
$\mathrm{pH}($ final) electrodes away PEM & 4.48 & 4.89 & 12.76 \\
Conductivity (initial) $\left(\mathrm{mS} \mathrm{cm}{ }^{-1}\right)$ & 15.69 & 12.33 & 6.02 \\
Conductivity (final) electrodes close PEM $\left(\mathrm{mS} \mathrm{cm}^{-1}\right)$ & 15.34 & 10.82 & 3.22 \\
Conductivity (final) electrodes away PEM $\left(\mathrm{mS} \mathrm{cm}^{-1}\right)$ & 15.34 & 12.34 & 30 \\
Temperature $\left({ }^{\circ} \mathrm{C}\right)$ constant & 30 & 30 & \\
\hline
\end{tabular}


Table 2 Variation of sugar concentration analysed at the electrodes near (A) and the electrodes far from (B) the Nafion membrane 117

\begin{tabular}{cllll}
\hline & Time (days) & Glucose $\left(\mathrm{g} \mathrm{L}^{-1}\right)$ & Fructose $\left(\mathrm{g} \mathrm{L}^{-1}\right)$ & Sucrose $\left(\mathrm{g} \mathrm{L}^{-1}\right)$ \\
\hline (A) & 0 & 0.08 & 0.06 & 3.10 \\
& 7 & 0.04 & 0.03 & 2.30 \\
& 14 & 0.01 & 0.01 & 1.56 \\
& 21 & - & - & 0.02 \\
& 28 & - & - & - \\
(B) & 0 & 0.08 & 0.06 & 3.10 \\
& 7 & 0.06 & 0.03 & 2.90 \\
& 14 & 0.04 & 0.01 & 2.20 \\
& 21 & - & & 0.97 \\
& 28 & - & & 0.09 \\
\hline
\end{tabular}

(a)

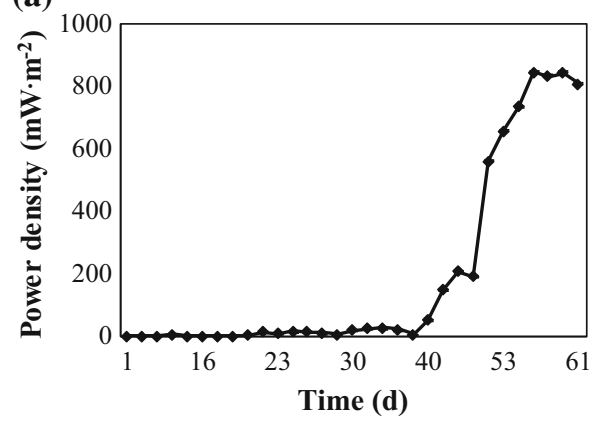

(b)

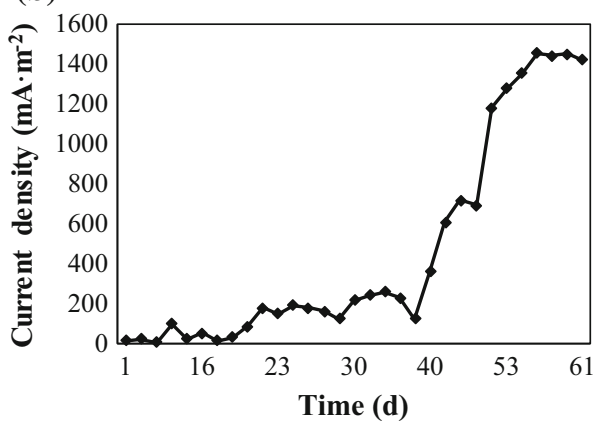

Fig. 2 Medium values of microbial fuel cells performance with electrodes in direct contact with the Nafion Membrane 117. Graphic a represents the power density $\left(\mathrm{mW} \mathrm{m}^{-2}\right)$, and $\mathbf{b}$ the current density $\left(\mathrm{mA} \mathrm{m}^{-2}\right)$

between the electrodes and the PEM was evaluated. With this purpose, a set of MFC had the electrodes adhered to the PEM and another set, had the electrodes at a distance of $3 \mathrm{~cm}$ from the PEM. The inoculum concentration was maintained at $10 \%$ in the anode chamber.

Considering the results obtained in our experiments, the best performance of MFCs occurred when the electrodes were closer (Fig. 2). This result is (a)

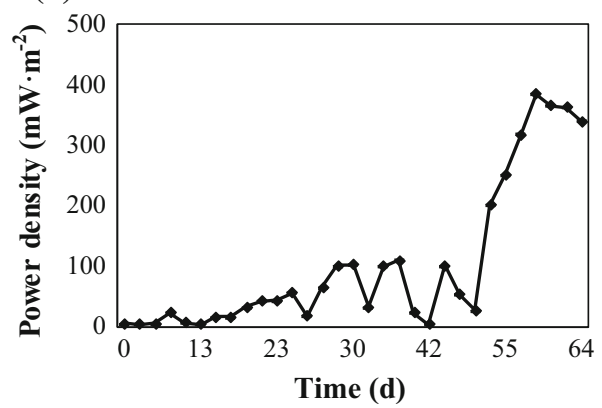

(b)

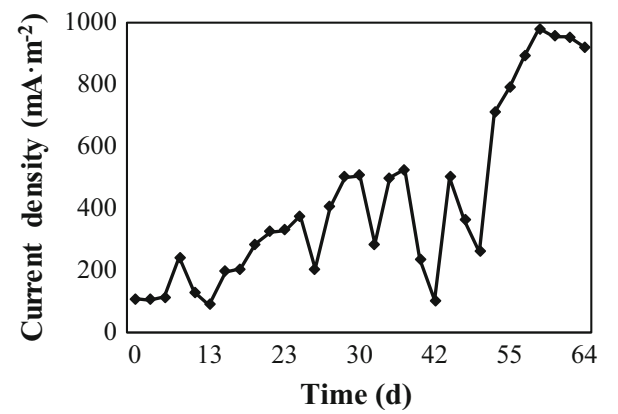

Fig. 3 Medium values of microbial fuel cells performance with electrodes at a distance of $3.0 \mathrm{~cm}$ from the Nafion Membrane 117. Graphic a represents the power density $\left(\mathrm{mW} \mathrm{m}^{-2}\right)$, and b the current density $\left(\mathrm{mA} \mathrm{m}^{-2}\right)$

consistent with the concept of fuel cell (FC; Association and Washington 1995) and also with other studies that used MFC to treat different residues (Santoro et al. 2014; Sharaf and Orhan 2014). Electrochemical monitoring of the MFC indicated

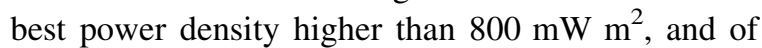
$33.61 \mathrm{~mW} \mathrm{~m}^{2}$ for the control. In comparison to the results obtained with the more distant electrodes of the 
(a)

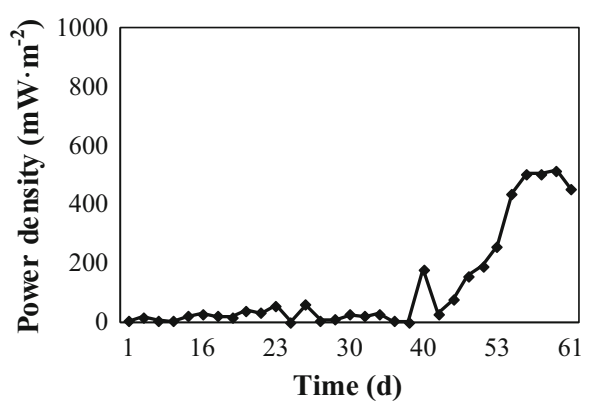

(b)

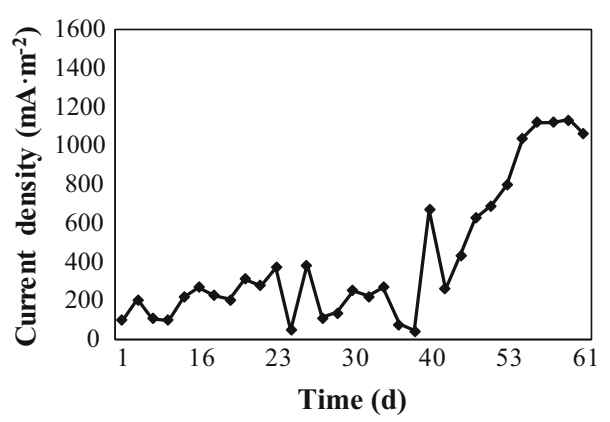

Fig. 4 Medium values of microbial fuel cells performance with electrodes in direct contact with the Membrane Nafion 117 and with $20 \%$ inoculum concentration in the anode chamber. Graphic a represents the power density $\left(\mathrm{mW} \mathrm{m}^{-2}\right)$, and $\mathbf{b}$ the current density $\left(\mathrm{mA} \mathrm{m}^{-2}\right)$

membrane (Fig. 3), the power density was two times higher, whereas the current density was approximately $0.7 \%$ lower than the one obtained in the best studied condition.

\section{Effect of inoculum concentration}

The effect of different inoculum concentrations, on the anode compartment of the MFC, was evaluated. For the MFC with the electrodes compacted to the PEM, the increase of the inoculum concentration promoted a negative effect in relation to the measures of COD, power density and, current density.

The COD measured at the end of the experiment at MFCs with inoculum concentrations of 20 and 30\%, was 22.4 and $18.1 \%$, respectively. The power density and current density measurements showed a linear decrease and an inverse relationship with inoculum concentration which increase along the time (Figs. 4, 5). Considering that, under anaerobic conditions the metabolism of organic matter triggers the formation of acids, this can result in microbial selection and (a)

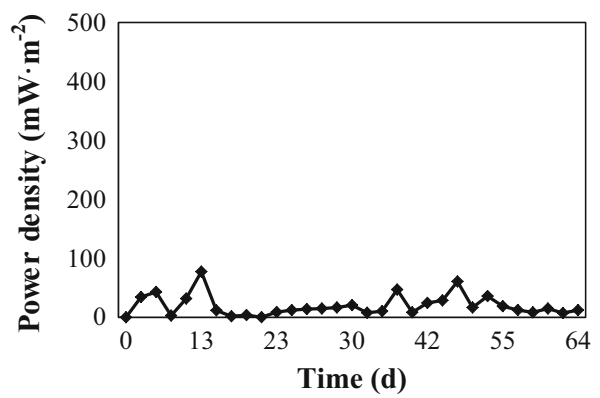

(b)

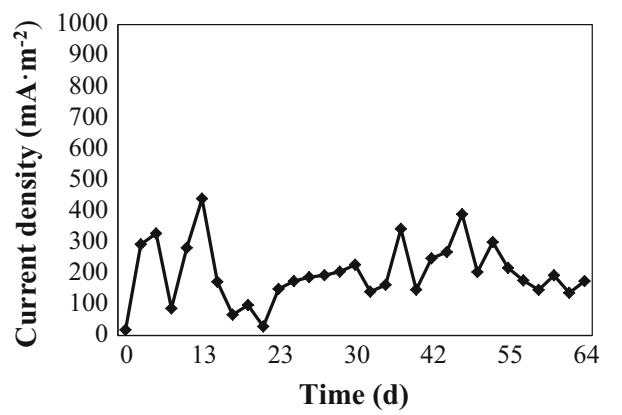

Fig. 5 Medium values of microbial fuel cells performance with electrodes in direct contact with Nafion Membrane 117 and 30\% inoculum concentration in the anode chamber. Graphic a represents the power density $\left(\mathrm{mW} \mathrm{m}^{-2}\right)$ and, $\mathbf{b}$ the current density $\left(\mathrm{mA} \mathrm{m}{ }^{-2}\right)$

inhibition (Gacitúa et al. 2018). Also, the reduced availability of easily metabolised organic matter can trigger a competition between the microorganisms, as well as the rapid formation of biofilm in the electrode and the PEM, reducing the efficiency in the transference of protons and electrons (Ullery and Logan 2015; Heidrich et al. 2018).

\section{Conclusion}

Taking our preliminary results into consideration, we concluded that the MFC technology presents itself as highly promising for the treatment of vinasse. Furthermore, the MFC prototype was done in PVC having a low cost and allowing for this research to be done more easily. However, further studies on the configuration and operation of the MFC are required for a higher number of cycles and scale-up. In addition, to further complement the knowledge on this technology, the microbial community that forms the biofilm in the 
anodic chamber should be characterised and identified.

Acknowledgements Authors would like to acknowledge the technician and financial support of Programa Novos Talentos provided by the Instituto de Pesquisa Tecnológica do Estado de São Paulo (IPT) and Instituto de Estudos Avançados do Mar (IEAMar).

Funding Instituto de Pesquisa Tecnológica do Estado de São Paulo/Programa Novos Talentos, through individual Research Grant attributed to Cristiane Angélica Ottoni.

\section{Compliance with ethical standards}

Conflict of interests All authors declare that they have no competing interests.

\section{References}

Alatraktchi FA, Zhang Y, Angelidaki I (2011) Nanomodification of the electrodes in microbial fuel cell: impact of nanoparticle density on electricity production and microbial community. Appl Energy 116:216-222

Association C, Washington D (1995) APHA: standard methods for the examination of water and wastewater. Am Phys Educ Rev 24:481-486

Campos CR, Mesquita VA, Silva CF, Schwan RF (2014) Efficiency of physicochemical and biological treatments of vinasse and their influence on indigenous microbiota for disposal into the environment. Waste Manag 34:2036-2046

Cassman NA, Lourenço KS, do Carmo JB, Cantarella H, Kuramae EE (2018) Genome-resolved metagenomics of sugarcane vinasse bactéria. Biotechnol Biofuels 11:48

Chakraborty C, Doss CG, Patra BC, Bandyopadhyay S (2014) DNA barcoding to map the microbial communities: current advances and future directions. Appl Microbiol Biotechnol 98:3425-3436

Christofoletti CA, Escher JP, Correia JE, Marinho JFU, Fontanetti CS (2013) Sugarcane vinasse: environmental implications of its use. Waste Manag 33:2752-2761

Engin IK, Cekmecelioglu D, Yücel AM, Oktem HA (2018) Evaluation of heterotrophic and mixotrophic cultivation of novel Micractinium sp. ME05 on vinasse and its scale up for biodiesel production. Bioresour Technol 251:128-134

Franks AE, Nevin KP (2010) Microbial fuel cells, a current review. Energies 3:899-919

Gacitúa MA, Muñoz E, González B (2018) Bioelectrochemical sulphate reduction on batch reactors: effect of inoculumtype and applied potential on sulphate consumption and pH. Bioelectrochemistry 119:26-32

Harde SM, Bankar SB, Ojamo H, Granström T, Singhal RS, Survase AS (2014) Continuous lignocellulosic ethanol production using Coleus forskohlii root hydrolysate. Fuel 126:77-84
Hassan SHA, El-Rab SMF, Rahimnejad M, Ghasemi M, Joo J-H, Sik-Ok Y, Kim IS, Oh S-E (2014) Electricity generation from rice straw using a microbial fuel cell. Int $\mathrm{J}$ Hydrog Energy 39:9490-9496

Heidrich ES, Dolfing J, Wade MJ, Sloan WT, Quince C, Curtis TP (2018) Temperature, inocula and substrate: contrasting electroactive consortia, diversity and performance in microbial fuel cells. Bioelectrochemistry 119:43-50

Hidalgo D, Tommasi T, Cauda V, Porro S, Chiodoni A, Bejtka K, Ruggeri B (2014) Streamlining of commercial Berl saddles: a new material to improve the performance of microbial fuel cells. Energy 71:615-623

Higa M, Calderani DA, Lopes KS (2014) Electric power generation from anaerobic digestion of the sugar cane vinasse-case study. Rev Eng Tecnol 6:83-91

Higgins SR, Lau C, Atanassov P, Minteer SD, Cooney MJ (2011) Hybrid biofuel cell: microbial fuel cell with an enzymatic air-breathing cathode. ACS Catal 1:994-997

Hou B, Hu Y, Sun J (2012) Performance and microbial diversity of microbial fuel cells coupled with different cathode types during simultaneous azo dye decolorization and electricity generation. Bioresour Technol 111:105-110

Huang L, Regan JM, Quan X (2011) Electron transfer mechanisms, new applications, and performance of biocathode microbial fuel cells. Bioresour Technol 102:316-323

Jadhav DA, Ghadge NA, Ghangrekar MM (2014) Simultaneous organic matter removal and disinfection of wastewater with enhanced power generation in microbial fuel cell. Bioresour Technol 163:328-334

Lima AM, Souza RR (2013) Use of sugar cane vinasse as substrate for biosurfactant production using Bacillus subtilis PC. Chem Eng Trans 37:673-678

Martínez SH, Eijck J, Cunha MP, Guilhoto JJM, Walter A, Faaij A (2013) Analysis of socio-economic impacts of sustainable sugarcane-ethanol production by means of inter-regional Input-Output analysis: demonstrated for Northeast Brazil. Renew Sustain Energy Rev 28:290-316

Mehdinia A, Ziaei E, Jabbari A (2014) Multi-walled carbon nanotube $/ \mathrm{SnO}_{2}$ nanocomposite: a novel anode material for microbial fuel cells. Electrochim Acta 130:512-518

Mohan SV, Velvizhi G, Modestra A, Srikanth S (2014) Microbial fuel cell: critical factors regulating bio-catalyzed electrochemical process and recent advancements. Renew Sustain Energy Rev 40:779-797

Moraes BS, Junqueira TL, Pavanello LG, Cavalett O, Mantelatto PE, Bonomi A, Zaiat M (2014) Anaerobic digestion of vinasse from sugarcane biorefineries in Brazil from energy, environmental, and economic perspectives: profit or expense? Appl Energy 113:825-835

Oliveira JG, Garcia-Cruz CH (2013) Properties of a biosurfactant produced by Bacillus pumilus using vinasse and waste frying oil as alternative carbon sources. Braz Arch Biol Technol 56:155-160

Oliveira BG, Carvalho JLN, Cerri CEP, Cerri CC, Feigl BJ (2013) Soil greenhouse gas fluxes from vinasse application in Brazilian sugarcane áreas. Geoderma 200-201:77-84

Ozkaya B, Akoglu B, Karadag D, Aci G, Taskan E, Hasar H (2012) Bioelectricity production using a new electrode in a microbial fuel cell. Bioprocess Biosyst Eng 35:1219-1227

Pant D, Bogaert GV, Diels L, Vanbroekhoven K (2010) A review of the substrates used in microbial fuel cells (MFCs) 
for sustainable energy production. Bioresour Technol 101:1533-1543

Peixoto L, Rodrigues AL, Martins G, Nicolau A, Brito AG, Silva MM, Parpot PR (2013) A flat microbial fuel cell for decentralized wastewater valorization: process performance and optimization potential. Environ Technol 34:1947-1956

Potentini MF, Rodríguez-Malavera J (2006) Vinasse biodegradation by Phanerochaete chrysosporium. J Environ Biol 27:661-665

Sá LRV, Cammarota MC, Ferreira-Leitão VS (2014) Produção de hidrogênio via fermentação anaeróbia - Aspectos gerais e possibilidade de utilização de resíduos agroindustriais brasileiros. Quim Nova 37:857-867

Santoro C, Guilizzoni M, Correa Baena JP, Pasaogullari U, Casalegno A, Li B, Babanova S, Artyushkova K, Atanassov P (2014) The effects of carbon electrode surface properties on bacteria attachment and start up time of microbial fuel cells. Carbon 67:128-139

Santos SC, Rosa PRF, Sakamoto IK, Varesche MBA, Silva EL (2014) Hydrogen production from diluted and raw sugarcane vinasse under thermophilic anaerobic conditions. Int $\mathrm{J}$ Hydrog Energy 39:9599-9610
Sharaf OZ, Orhan MF (2014) An overview of fuel cell technology: fundamentals and applications. Renew Sustain Energy Rev 32:810-853

Sydney EB, Larroche C, Novak AC, Nouaille R, Sarma SJ, Brar SK, Letti LAJ, Soccol VT, Soccol CR (2014) Economic process to produce biohydrogen and volatile fatty acids by a mixed culture using vinasse from sugarcane ethanol industry as nutrient source. Bioresour Technol 159:80-386

Ullery ML, Logan BE (2015) Anode acclimation methods and their impact on microbial electrolysis cells treating fermentation effluent. Int J Hydrog Energy 40:6782-6791

Wei J, Liang P, Huang X (2011) Recent progress in electrodes for microbial fuel cells. Bioresour Technol 102:9335-9344

Yang F, Hanna MA, Sun R (2012) Value-added uses for crude glycerol-a byproduct of biodiesel production. Biotechnol Biofuels 5:1-13

Zhang Y, Min B, Huang L, Angelidaki I (2011) Electricity generation and microbial community response to substrate changes in microbial fuel cell. Bioresour Technol 102:1166-1173 